Bull. Fac. Agric., Cairo Univ., 71:15-24 (2020).

\title{
IMPACT OF SOME HERBICIDES, DIFFERENT MULCHING AND THEIR INTEGRATING ON MAIZE PRODUCTIVITY AND CONTROLLING ASSOCIATED WEEDS.
}

(Received: 26.2.2020)

\author{
By \\ Rasha G.M. Abo El-Hassan \\ Weed Control Central Laboratory Research, Agricultural Research Center, Giza, Egypt
}

\begin{abstract}
A field experiment was carried out during two successive summer seasons 2018 and, repeated, on 2019 at Sids Agricultural Research Station Farm, A.R.C., Bani Swif Governorate, Egypt; to study the effect of different weed control treatments on yield, yield components, quality and associated weeds of maize. Each field trail included the following treatments: a) Mulching with black and green polyethylene sheets, b) Mulching with rice or wheat, straw c) Herbicides (Atazan 75\% WG at 50 $\mathrm{g} /$ fed. and Steler star $21 \% \mathrm{SL}$ at $300 \mathrm{~cm}^{3} /$ fed.) both at full rate (alone) and at reduced rate with their integration by different mulching or with adding mineral oil, beside, Maister power $4.53 \%$ OD, at full rate alone $\left(500 \mathrm{~cm}^{3} / \mathrm{fed}\right.$.), with hand hoeing twice at 20 and 40 days after sowing and weedy check. Each experiment was laid out in a Randomized Complete Blocks Design with four replicates. The results showed that both Atazan $75 \% \mathrm{WG}$ and Steler star $21 \% \mathrm{SL}$ at reduced rate $50 \%$ of full rate $(25 \mathrm{~g}$ and $150 \mathrm{~cm}^{3} /$ fed., respectively) combined with mulching rice or wheat straw (both of them at 10 ton/fed.), also, the same herbicides at reduced rate $25 \%$ of full rate $\left(37.5 \mathrm{~g} / \mathrm{fed}\right.$. and $225 \mathrm{~cm}^{3} / \mathrm{fed}$., respectively) with adding mineral oil at $1 \%$ gave superiority a significant differences whereas, weed control efficiency of Atazan combinations reached to $(87.8,86.8$ and $84.3 \%$ ), while Steler star combinations were (88.6, 87.6 and 84.9\%), compared to full rate of each Atazan and Steler star alone (69.0 and $73.8 \%$, respectively) in the first season. In the second season the same trend was achieved as the previous treatments. Concerning grain yield, its components and quality characters of maize; the results revealed that combinations of Atazan $75 \% \mathrm{WG}$ and Steler star $21 \% \mathrm{SL}$ at reduced rate $50 \%$ of full rates $\left(25 \mathrm{~g} / \mathrm{fed}\right.$. and $150 \mathrm{~cm}^{3} / \mathrm{fed}$., respectively) with rice or wheat straw (both at 10 ton/fed.) gave the highest values over both Atazan 75\%WG and Steler star 21\%SL at reduced rate 25\% (37.5 g/fed. and $225 \mathrm{~cm}^{3} /$ fed., respectively) with mineral oil. But all these combinations gave significant increase compared to both Atazan $75 \% \mathrm{WG}$ or Steler star21\% SL at full rate alone, in the first and second seasons. Therefore, it could be concluded from this study; using integrated mulching or mineral oil with reduced doses of herbicides will achieve more efficiency weed control than herbicides at full rate alone without loss in maize yield and its components.
\end{abstract}

Key words: Maize, Zea mays L., Mulches, Herbicide, Adjuvants, Weed control.

\section{INTRODUCTION}

Maize (Zea mays L.) is the third most important cereal crop after wheat and rice in the world; and plays an important role in agricultural economy. In Egypt, maize occupies special position in the national economy, whereas it is a multipurpose crop (i.e. used as human food, animals and poultry feed; also produces row materials for starch industry and used in the preparation of other product. The total consumption of maize is about 14 million tons, while the total maize production is about 3 million tons. Therefore, there is a gap between the consumption and the local maize production, which means that Egypt has to import about 9 million tons annually. The total cultivated area of maize in 2018 was about 2, 30 million feddans. (Agricultural Statistics, 2019). In spite of high yielding potential of maize, its productivity is still very low in comparison with advanced countries. Although several high yielding varieties are developed and released but still the required potential yield could not be achieved. This is mostly due to absented or less importance given to the weed control practices by the farmers (Khaliq et al., 2004).

Weeds negatively impact crop yields, interfere with many crop production practices, 
and weed seeds can contaminate grain. Based on national research; maize yield can be reduced by approximately $50 \%$ in absence of effective weed control. Also, weeds act as the host for many insects and pests causing major diseases and troubles during cultural practices, ultimately production excessive cost. However, maize yield losses caused by weed competition amounts to 50\% (Abouziena et al. 2013) and $33.7 \%$ (Saudy, 2013)

Therefore, weed control is necessary for obtaining good yield. Different weed control methods have been used to manage the weeds, but mechanical and chemical methods are more frequently used for weeds control than any other control methods. Mechanical methods including hand weeding and hoeing are still useful but are getting expensive; laborious and timeconsuming.

Herbicides have become a vital component for weed management. These, not only control the weeds and increase yield, but also save energy, labour, time and reduce erosion and farming cost (Anonymous, 2006). Also, there are major concerns in modern agriculture (Afzal et al., 2015). However, the heavy use of herbicides has given rise to serious environmental pollution and public health problems (Sopena et al., 2009)

Reliance on one herbicide application has led to the development of herbicides-resistant weeds, and number of available herbicide options gets greatly reduced (Knezevic et al., 2017b).

Therefore, to overcome these problems, other weed control methods could be adopted. In recent years, weed control programs have often focused on non-chemical weed control (cultural, mechanical and biological) safety methods, or are generally "environmental or eco-friendly". So that, research's are moving towards other alternative methods for weed control as mulching (Varga et al., 2011; Mahmoodi and Ali 2009). Mulch is a material that covers the soil surface, which is two types' i.e. organic mulch (living/ natural) including legumes straw, cereal straw or crop residues like banana leaves, etc. (Monks et al., 1997, Silva et al., 2015), and inorganic mulch (synthetic/non-living) including polyethylene (plastic), polypropylene sheets or film etc. (Rao, 2000).

No doubt mulching is still useful, but not effective to weed control alone. Therefore, using a variety of weed control methods reduces the reliance on any method alone, which means that those methods will be effective and keep weeds off-balance and prevents them from adapting to the management strategy (Knezevic et al., 2017a and 2017b).

Therefore, the present study was conducted to evaluate the effectiveness of herbicides at full rate (alone) and at reduced rate ( $25 \%$ of full rate) with mineral oil at $(1 \%)$, and determine the effect of combined herbicide at reduced rate with different type of mulching to achieve a better management of weed control methods, and teach the highest quantity and quality of maize yield and its components.

\section{MATERIALS AND METHODS}

A Field experiment was conducted during 2018 and repeated in 2019, at Sids Agricultural Research Station, Agricultural Research Center (A.R.C.) Egypt, to evaluate the treatments including herbicides at full rate (alone) and reduced rate with mineral oil, different mulching alone and there integrations.

Each field trial included the following treatments:

1. Black poly-ethylene mulch $0.150 \mathrm{~mm}$ thick covering soil surface and holes by using mineral tubes with sharp edge, with $25 \mathrm{~cm}$ distance between holes.

2. Green poly-ethylene mulch $0.150 \mathrm{~mm}$ thick covering soil surface and holes by using mineral tubes with sharped edge with $25 \mathrm{~cm}$ distance between holes.

3. Rice straw (Oryza sativa L.) mulch; at 10 ton/fed., by $25 \mathrm{~kg} / \mathrm{plot}$ covering the furrow between plants and ridges.

4. Wheat straw (Triticum spp) mulch; at 10 ton/fed., by $25 \mathrm{~kg} / \mathrm{plot}$ covering the furrow between plants and ridges.

5. Nicosulfuron "Atazan $75 \%$ WG" used at full rate $50 \mathrm{~g} / \mathrm{fed}$., applied as post emergence.

6. Nicosulfuron at reduced rate $25 \%$ of full rate $(37.5 \mathrm{~g} / \mathrm{fed}$.) + Mineral oil at $1 \%$ as post emergence.

7. Nicosulfuron at reduced rate $50 \%$ of full rate ( $25 \mathrm{~g} /$ fed.) followed by rice straw as covering in the furrow between plants and ridges.

8. Nicosulfuron at reduced rate $50 \%$ of full rate $(25 \mathrm{~g} /$ fed.) followed by wheat straw as covering the furrow between plants and ridges.

9. Dicamba + Toramezone "Steler Star $21 \%$ SL" used at full rate $300 \mathrm{~cm}^{3} /$ fed., applied as post-emergence. 
10. Dicamba + Toramezone at reduced rate $25 \%$ of full rate $\left(225 \mathrm{~cm}^{3} /\right.$ fed. $)+$ Mineral oil at $1 \%$ as post - emergence.

11. Dicamba + Toramezone at reduced rate $50 \%$ of full rate $\left(150 \mathrm{~cm}^{3} /\right.$ fed.) followed by rice straw as cover in the furrow between plants and ridges.

12. Dicamba + Toramezone at reduced rate $50 \%$ of full rate $\left(150 \mathrm{~cm}^{3} /\right.$ fed. $)$ followed by wheat straw as a cover in the furrow between plants and ridges.

13. Foramsulfuron sodium $3.35 \%+$
The following Table (1) explained herbicide treatments.

A Randomized Complete Block Design (RCBD) with four replicates was used. Each plot area was $10.5 \mathrm{~m}^{2}$ (5 rows $X 3.0 \mathrm{~m}$ length). The row-to row and plant-to-plant distances were 70 $\mathrm{cm}$ and $25 \mathrm{~cm}$, respectively. Maize cultivar "single cross 128" (Zea mays L.) obtained from Sids Agricultural Research Station, Agricultural Research Center (A.R.C.) Egypt, and used in both seasons. Maize grains were sown manually on one side in hills at the rate of $10 \mathrm{Kg} / \mathrm{fed}$,

Table (1): Trade, common and chemical names, family group and site of action of the herbicides according to The Pesticide Manual (2012) and according to (WSSA, 2011) classification.

\begin{tabular}{|c|c|c|c|c|c|}
\hline $\begin{array}{l}\text { Trade } \\
\text { name }\end{array}$ & $\begin{array}{c}\text { Common } \\
\text { name }\end{array}$ & Chemical name & $\begin{array}{l}\text { Family } \\
\text { group }\end{array}$ & $\begin{array}{l}\text { Site of } \\
\text { Action }\end{array}$ & $\begin{array}{l}\text { WSSA } \\
\text { Group }\end{array}$ \\
\hline $\begin{array}{l}\text { Atazan75 \% } \\
\text { WG" }\end{array}$ & Nicosulfuron & $\begin{array}{c}\text { [2-[(4, 6-dimethoxy- } \\
\text { pyrimidinyl) amino] carbonyl] } \\
\text { amino] sulfonyl]-N, Ndimethyl- } \\
\text { 3-pyridinecarboxamide] }\end{array}$ & sulfonylurea & $\begin{array}{l}\text { Inh. } \\
\text { (ALS/ } \\
\text { AHAS) } \\
\text { synth. }\end{array}$ & 2 \\
\hline $\begin{array}{l}\text { Steler Star } \\
21 \% \mathrm{SL}\end{array}$ & $\begin{array}{c}\text { Dicamba } \\
+ \\
\text { Toramezone }\end{array}$ & $\begin{array}{l}\text { [3,6-dichloro-2-methoxybenzoic } \\
\text { acid] + [GY-HMax, methylated } \\
\text { soybean oil, adjuvant] }\end{array}$ & $\begin{array}{l}\text { benzoic acid } \\
\text { auxin }+ \\
\text { adjuvant }\end{array}$ & $\begin{array}{l}\text { Synthet } \\
\text { ic auxin }\end{array}$ & 4 \\
\hline \multirow{3}{*}{$\begin{array}{l}\text { Maister } \\
\text { power } 4.53 \\
\% \text { OD }\end{array}$} & $\begin{array}{l}\text { Foramsulfuron } \\
\text { sodium } 3.35 \%\end{array}$ & $\begin{array}{c}\text { [2-[[[[(4, 6-dimethoxy-2- } \\
\text { pyrimidinyl) amino] carbonyl] } \\
\text { amino] sulfonyl]-4- } \\
\text { (formylamino)- } N, N \\
\text { dimethylbenzamide }]+\end{array}$ & \multirow{3}{*}{ sulfonylurea } & \multirow{3}{*}{$\begin{array}{l}\text { Inh. } \\
\text { (ALS/ } \\
\text { AHAS) } \\
\text { synth }\end{array}$} & \multirow{3}{*}{2} \\
\hline & \begin{tabular}{|} 
Iodosulfuron- \\
methyl sodium \\
$0.11 \%$
\end{tabular} & $\begin{array}{l}\text { [methyl 4-iodo-2-[[[[(4- } \\
\text { methoxy- 6-methyl-1,3,5- } \\
\text { triazin-2yl)amino] carbonyl] } \\
\text { amino] sulfonyl] benzoate, } \\
\text { sodium salt }]+\end{array}$ & & & \\
\hline & $\begin{array}{l}\text { Thiencarbazone } \\
\text {-methyl } 1.07 \%\end{array}$ & $\begin{array}{l}\text { [methyl 4- [[[(4,5-dihydro-3- } \\
\text { methoxy-4- methyl-5-oxo- } 1 H \text { - } \\
\text { 1,2,4-triazol-1- yl) carbonyl] } \\
\text { amino] sulfonyl]-5- methyl-3- } \\
\text { thiophenecarboxylate] }\end{array}$ & & & \\
\hline $\begin{array}{l}\text { Super Royal } \\
\text { Oil } 95 \% \text { EC }\end{array}$ & \multicolumn{2}{|c|}{ Aliphatic hydrocarbons } & Mineral oil & & \\
\hline
\end{tabular}

Iodosulfuron-methyl sodium $0.11 \%+$ Thiencarbazone-methyl $1.07 \%$ "Maister power $4.53 \%$ OD" used at full rate 500 $\mathrm{cm}^{3} /$ fed., applied as post - emergence.

14. Hoeing twice: at 20 and 40 days after sowing (DAS).

15. Untreated (control). during the $1{ }^{s t}$ week of June in both seasons. The seedlings were thinned to one plant per hill before the $1^{s t}$ irrigation. The culture practices for maize production were managed in accordance with the local recommendations. Herbicides were applied at 3-6 leaf stage of maize as postemergence using "Knapsack hand sprayer $\mathrm{CP}_{3}$ " equipped with one nozzle even flat fan calibrated 
to deliver spray volume of $200 \mathrm{~L} /$ fed. Harvested was done on the $1^{s t}$ week of October in both seasons. The soil texture of the experiments was heavy clay in both seasons.

\subsection{The following data were recorded \\ 2.1.1. Weed Survey}

Weed species from one square meter chosen at random from each plot were hand pulled out and identified at the species level using the weed identification manual of (Täckholm, 1974), then separated into two groups i.e. broad-leaved, grasses and total weeds. Weed survey was carried out after 60 days from sowing. Weed control efficiency (WCE) was calculated as follow:

FWC - FWT

$\mathrm{WCE} \%=\frac{}{\mathrm{FWC}} \times 100$

Where, $\mathrm{FWC}=$ Fresh weight of weeds from control plot and FWT $=$ Fresh weight of weeds from treated plot.

\subsubsection{Yield and its components}

At harvest, samples of ten plants were randomly taken from the central area of each plot to estimate the following traits: Plant height $(\mathrm{cm})$, ear height $(\mathrm{cm})$, ear diameter $(\mathrm{cm})$, number of rows/ ear, number of grains/row, Ear grains weight $(\mathrm{g}), 100$ grains weight $(\mathrm{g})$.

Grain yield ardab/feddan $(1 \mathrm{ardab}=140 \mathrm{~kg})$ was calculated based on weight of grains yield obtained from each plot, the weights were adjusted to $15.5 \%$ moisture content

\subsubsection{Maize grains quality}

2.1.3.1. Determination of protein in maize grains: The total nitrogen was determined by micro-kjeldahl method according to A.O.A.C. (2000)

2.1.3.2. Determination of carbohydrates in maize grains: the total carbohydrate percentage was determined according to A.O.A.C. (2000).

\subsubsection{Statistical Analysis}

All data obtained were statistically analyzed according to (Gomez and Gomez 1984). Duncan (1955) multiple range tests were used for the comparison among means.

\section{RESULTS AND DISCUSSION}

\subsection{Effect of weed control treatments on}

\subsection{1. weeds}

During both maize growing seasons in the experimental site the major weeds flora identification and classification included Portulaca oleracea, L., Amaranthus cruentus, L., Sida alba, L., Xanthium strumarium, $\mathrm{L}$ and Euphorbia geniculata, L. as broad-leaf weeds, while Brachiaria repans, L. and Echinochloa colonum, L. as grasses.

The results showed (Table 2) that there was no significant differences between both organic mulching (rice and wheat straw), but rice straw gave higher weed control efficiency than wheat straw, whereas controlling efficacy reached to (62.6, 61.8\% and 63.1, 62.6\%, respectively in first and second seasons). As for the inorganic mulching black and green polyethylene sheets there were no significant differences between them, but black polyethylene sheets gave better controlling efficiency than the green polyethylene sheets reaching to $55.6,53.0 \%$ and $54.8,51.7 \%$, in the first and the second seasons, respectively).

The data revealed that the combinations between the herbicides at reduced rate $50 \%$ followed by mulching with rice or wheat straw and also, these herbicides at reduced rate $25 \%$ with adding mineral oil at $1 \%$ were significantly superior in weed control than the herbicides at full rate alone, without any significant differences between all these combinations. The controlling effect of the combinations Atazan $75 \% \mathrm{WG}$ at reduced rate $50 \%(25 \mathrm{~g} /$ fed. $)$, followed by both rice or wheat straw (both of them at 10 ton/fed.) and at reduced rate $25 \%$ $(37.5 \mathrm{~g})$ with mixture of mineral oil at $1 \%$ were $(87.8,86.8$ and $84.3 \%)$, and the similar trend was obtained by Steler star $21 \%$ SL at reduced rate $50 \%\left(150 \mathrm{~cm}^{3}\right)$ followed by mulching or at reduced rate $25 \%\left(225 \mathrm{~cm}^{3} /\right.$ fed.) tank mix with mineral oil gave superior a significant differences, whereas weed control efficiency reached to (88.6, 87.6 and $84.9 \%$, respectively) compared to the full rate of (Atazan and Steler star) alone reached to $(69.0 \%$ and $73.8 \%$, respectively), in the first season. In the second season the same trend was achieved, whereas the combinations of Atazan were superior (82.7, 80.1 and $74.9 \%$ ) than Atazan at full rate $(70.9 \%)$. Also, the same altitudes were the combinations of Steler star $(87.6,84.3$ and $81.1 \%)$, than at full rate alone $(74.6 \%)$.

Moreover, there were no significant differences between Maister power at the full rate $\left(500 \mathrm{~cm}^{3} / \mathrm{fed}\right.$.) and hand hoeing twice whereas the controlling effects were $(83.3$ and $81.4 \%$ ) and ( 86.1 and $82.3 \%$ respectively), in the 
Table (2): Effect of mulching with herbicides in combinations on fresh weight of total weeds $\left(\mathrm{gm} / \mathrm{m}^{2}\right)$ in 2018 and 2019 seasons.

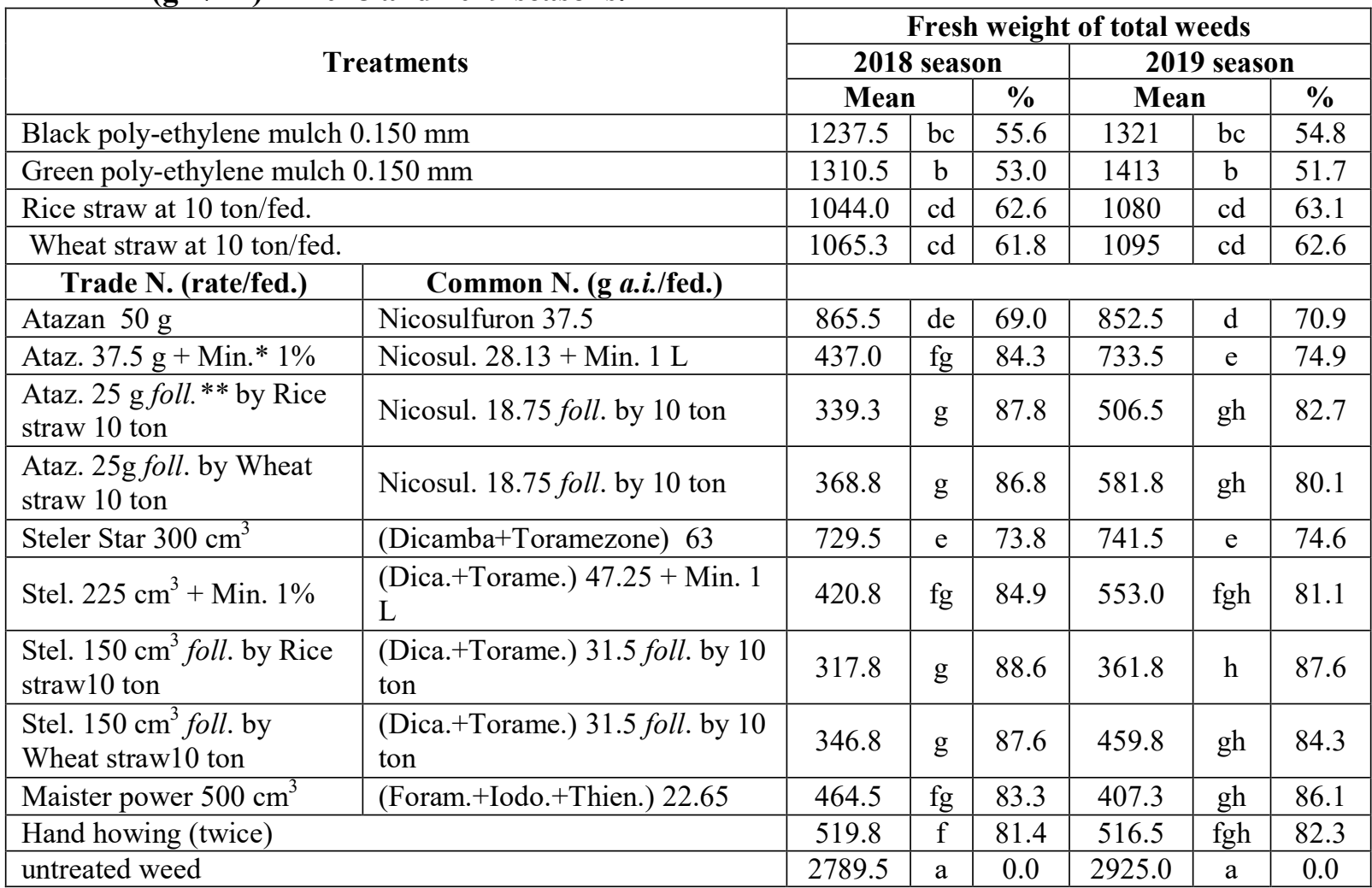

*Min. $=$ Mineral oil. $* *$ foll. $=$ followed.

Any two means in the same column sharing same letters did not differ significantly by Duncan at $5 \%$ level of probability.

first and the second seasons.

The results obtained, from this study showed that all combinations used (herbicides with mulching) were better than any methods alone. Therefore these combinations gave effective and keept weeds off-balance and prevented them from adapting to the management strategy (Knezevic et al., 2017a and 2017b). The individual Atazan and steler star at full rate alone gave significantly less weed control than the combinations of these herbicides at reduced rate $50 \%$ with different mulching or at reduced rate $25 \%$ with mineral oil $1 \%$, because both Atazan and steler star at full rate alone contain one active ingredient, controlling only some weed species especially if weeds community has many and different species. Also, they have relatively short time of action; thus provide only narrow spectrum of weed control (Amin et al., 2008). Also, There were no significant differences in the efficiency of weed control between their combinations and maister power at full rate alone because this herbicide contains three active ingredients, therefor provide a wide spectrum of weed control. Other, researchers (Teasdale and Mohler, 2000) and (Bond and
Grundy, 2001) found the same trend whereas the combination of herbicides at reduced rate $50 \%$ of full rate with mulching (straw) prevent weed seeds germination by blocking the light required for weed seed germination or inhibits weeds growth due to its allelopathic effect. In the same line, Devendra et al., (2004) found that it may be possible to optimize the efficiency of herbicides at reduced rates by addition of adjuvant or combination with other alternative methods. So, they are moving towards other alternative methods of weed control as mulching (Varga et al., 2011; Mahmoodi and Ali 2009).

\subsubsection{Maize yield and its components}

The data in Tables (3 and 4) showed that the effect of combinations both herbicides Atazan or Steler star at reduced rate with mulching rice or wheat straws gave significant increased plant height $(\mathrm{cm})$ where long stature plants in Atazan combinations were $(231.5$ and $231.0 \mathrm{~cm})$, while in Steler star combinations were (232.3 and $230.5 \mathrm{~cm})$ in first season and $(219.3,218.8$, 219.5 and $218.5 \mathrm{~cm}$, respectively) in the second season. The previous combinations gave more values than both herbicides at the reduced rate with mineral oil at $1 \%$, and maister power at full 
rate alone. All combinations were more significant than Atazan and/or Steler star at full rate alone, Whereas, Fazal et al., (2009) found that plant height is a key factor that contributes significantly to grain yield because taller plants have many leaves that can capture more light and therefore had more photosynthetic available for grain filling.

Similar trends were observed in yield components (ear length $(\mathrm{cm})$, ear diameter $(\mathrm{cm})$, weight of grains/ears and weight 100 grains $(\mathrm{g})$ ) in both seasons. These results are in agreement with Noor et al. (2012) who concluded that the increase in maize crop grain yield was directly correlated with the increase in yield components and decrease in density and dry biomass of weeds.

Grain yield is an important parameter and function of an interaction among various yield components, which are affected differently by the growing conditions and crop management practices. The data in Table (4) revealed that mulching with rice and wheat straw gave satisfactory grain yield (16.63 and 16.35 ardab/fed.) than the black and green polyethylene sheets (15.11 and $14.38 \mathrm{ardab} / \mathrm{fed}$., respectively), in the first season and (15.70, $15.05,13.95$ and 13.35 ardab/fed., respectively) in the second season. These results are in harmony with Elmer, (2000) and Revathy, 2003) who stated that mulching practice can increase crop growth, grain yield and weeds control. In the same line (Rahman et al., 2002) reported that straw mulching brings favorable soil environment and soil moisture conditions which in turn increased the dry matter accumulation in plant. Also, other researchers (Bond and Grundy, 2001) investigated the effects of mulching on inhibiting weeds, as they reduce light interception, alter soil temperature, physically

Table (3): Effect of mulching with herbicides in combinations on yield components in 2018 and 2019 seasons.

\begin{tabular}{|c|c|c|c|c|c|c|}
\hline \multirow{2}{*}{ Treatments } & \multicolumn{2}{|c|}{ Plant height (cm) } & \multicolumn{2}{|c|}{ Ear Length (cm) } & \multicolumn{2}{|c|}{ Ear diameter $(\mathbf{c m})$} \\
\hline & $\begin{array}{c}2018 \\
\text { season }\end{array}$ & $\begin{array}{c}2019 \\
\text { season }\end{array}$ & $\begin{array}{c}2018 \\
\text { season }\end{array}$ & $\begin{array}{c}2019 \\
\text { season }\end{array}$ & $\begin{array}{c}2018 \\
\text { season }\end{array}$ & $\begin{array}{c}2019 \\
\text { season }\end{array}$ \\
\hline $\begin{array}{l}\text { Black poly-ethylene } \\
\text { mulch } 0.150 \mathrm{~mm}\end{array}$ & 215.3 ef & $206.8 \mathrm{de}$ & $15.13 \mathrm{de}$ & $14.75 \mathrm{f}$ & $3.61 \mathrm{def}$ & $3.56 \mathrm{~b}$ \\
\hline $\begin{array}{l}\text { Green poly-ethylene } \\
\text { mulch } 0.150 \mathrm{~mm}\end{array}$ & $213.3 \mathrm{f}$ & $205.5 \mathrm{e}$ & $14.50 \mathrm{de}$ & $13.88 \mathrm{fg}$ & $3.38 \mathrm{f}$ & 3.13 ef \\
\hline Rice straw at 10 ton/fed. & 218.5 cde & $211.3 \mathrm{bcd}$ & $21.00 \mathrm{c}$ & $16.50 \mathrm{e}$ & $3.78 \mathrm{cde}$ & $3.64 \mathrm{bcd}$ \\
\hline $\begin{array}{l}\text { Wheat straw at } 10 \\
\text { ton/fed. }\end{array}$ & $216.5 \mathrm{def}$ & 208.8 cde & $19.50 \mathrm{c}$ & $14.55 \mathrm{f}$ & $3.63 \mathrm{def}$ & $3.58 \mathrm{bcd}$ \\
\hline \multicolumn{7}{|l|}{ Trade N. (rate/fed.) } \\
\hline Atazan $50 \mathrm{~g}$ & $218.0 \mathrm{cde}$ & $204.8 \mathrm{e}$ & $15.75 \mathrm{~d}$ & $16.13 \mathrm{e}$ & $3.50 \mathrm{ef}$ & $3.38 \mathrm{def}$ \\
\hline Ataz. $37.5 \mathrm{~g}+$ Min. ${ }^{*} 1 \%$ & $220.0 \mathrm{bcd}$ & 207.3 cde & $20.88 \mathrm{c}$ & $20.38 \mathrm{~d}$ & $4.00 \mathrm{bc}$ & $3.63 \mathrm{bcd}$ \\
\hline $\begin{array}{l}\text { Ataz. } 25 \mathrm{~g} \text { foll. } * * \text { by Rice } \\
\text { straw } 10 \text { ton }\end{array}$ & $231.5 \mathrm{a}$ & $219.3 \mathrm{a}$ & $25.50 \mathrm{a}$ & $24.75 \mathrm{a}$ & $4.69 \mathrm{a}$ & $4.63 \mathrm{a}$ \\
\hline $\begin{array}{l}\text { Ataz. } 25 \mathrm{~g} \text { foll. by Wheat } \\
\text { straw } 10 \text { ton }\end{array}$ & $231.0 \mathrm{a}$ & $218.8 \mathrm{a}$ & $24.88 \mathrm{ab}$ & $24.25 \mathrm{a}$ & $4.63 \mathrm{a}$ & $4.50 \mathrm{a}$ \\
\hline Steler Star $300 \mathrm{~cm}^{3}$ & $219.5 \mathrm{~b}-\mathrm{e}$ & $212.0 \mathrm{bc}$ & $20.00 \mathrm{c}$ & $21.13 \mathrm{~cd}$ & $3.94 \mathrm{c}$ & $3.50 \mathrm{cde}$ \\
\hline Stel. $225 \mathrm{~cm}^{3}+$ Min. $1 \%$ & $223.5 \mathrm{~b}$ & $215.5 \mathrm{ab}$ & $23.50 \mathrm{~b}$ & $22.88 \mathrm{~b}$ & $4.25 \mathrm{~b}$ & $3.81 \mathrm{bc}$ \\
\hline $\begin{array}{l}\text { Stel. } 150 \mathrm{~cm}^{3} \text { foll. by } \\
\text { Rice straw } 10 \text { ton }\end{array}$ & $232.3 \mathrm{a}$ & $219.5 \mathrm{a}$ & $25.25 \mathrm{a}$ & $24.88 \mathrm{a}$ & $4.81 \mathrm{a}$ & $4.69 \mathrm{a}$ \\
\hline $\begin{array}{l}\text { Stel. } 150 \mathrm{~cm}^{3} \text { foll. by } \\
\text { Wheat straw } 10 \text { ton }\end{array}$ & $230.5 \mathrm{a}$ & $218.5 \mathrm{a}$ & $24.75 \mathrm{ab}$ & $24.50 \mathrm{a}$ & $4.69 \mathrm{a}$ & $4.64 \mathrm{a}$ \\
\hline Maister power $500 \mathrm{~cm}^{3}$ & $224.0 \mathrm{~b}$ & $215.5 \mathrm{ab}$ & $20.50 \mathrm{c}$ & $22.00 \mathrm{bc}$ & $4.25 \mathrm{~b}$ & $3.94 \mathrm{~b}$ \\
\hline Hand howing (twice) & $221.3 \mathrm{bc}$ & $212.0 \mathrm{bc}$ & $20.25 \mathrm{c}$ & $21.25 \mathrm{~cd}$ & $3.88 \mathrm{~cd}$ & $3.63 \mathrm{bcd}$ \\
\hline untreated weed & $180.8 \mathrm{~g}$ & $171.3 \mathrm{f}$ & $13.95 \mathrm{e}$ & $13.25 \mathrm{~g}$ & $3.06 \mathrm{~g}$ & $3.00 \mathrm{f}$ \\
\hline
\end{tabular}

*Min. $=$ Mineral oil. $* *$ foll. $=$ followed.

Any two means in the same column sharing same letters did not differ significantly by Duncan at $5 \%$ level of probability. 
hinder emergence and through the release of phytotoxic chemicals (allelopathy).

It is clear from Table (4) that the grain yield was significantly affected by all combination treatments, whereas, Atazan at the reduced rate with mulching both rice and wheat straw gave increased grain yield over Atazan at the reduced rate with mineral oil; But these combinations gave significantly superior results compared to Atazan at full rate alone by $(26.19,26.15,23.05$ and $16.50 \mathrm{ardab} / \mathrm{fed}$., respectively). Similar trend was found by Steler star in combinations (26.14, $25.27,23.0$ and 17.22 ardab/fed., respectively) in the first season, and similar altitude in the second season. untreated treatment. The combinations between the herbicides at the reduced rate $50 \%$ followed by mulching with rice or wheat straw, also, with adding mineral oil exceeded the rest of other treatments for enhancing carbohydrate and protein percentages. The highest carbohydrate and protein percentage were in combinations of Atazan at the reduced rate 50\% (25 g) followed by both of rice or wheat straw (both of them at 10 ton/fed.) and at reduced rate $25 \%(37.5 \mathrm{~g})$ with adding mineral oil, whereas carbohydrate were $(86.5,84.8$ and $80.5 \%$ ), while protein were $(10.0,9.5$ and $8.2 \%)$ respectively. Similar trend was obtained by Steler star at the reduced rate $\left(150 \mathrm{~cm}^{3}\right)$ followed by mulching and Steler star

Table (4): Effect of mulching with herbicides in combinations on grain yield (ardab/fed.) and its components in 2018 and 2019 seasons.

\begin{tabular}{|c|c|c|c|c|c|c|}
\hline \multirow{2}{*}{ Treatments } & \multicolumn{2}{|c|}{$\begin{array}{c}\text { Weight of grains / } \\
\text { ears }\end{array}$} & \multicolumn{2}{|c|}{$\begin{array}{l}\text { Weight of } 100 \\
\text { grains (g) }\end{array}$} & \multicolumn{2}{|c|}{$\begin{array}{l}\text { Grain yield } \\
\text { ardab/fed. }\end{array}$} \\
\hline & $\begin{array}{c}2018 \\
\text { season }\end{array}$ & $\begin{array}{c}2019 \\
\text { season }\end{array}$ & $\begin{array}{c}2018 \\
\text { season }\end{array}$ & $\begin{array}{c}2019 \\
\text { season }\end{array}$ & $\begin{array}{c}2018 \\
\text { season }\end{array}$ & $\begin{array}{c}2019 \\
\text { season }\end{array}$ \\
\hline $\begin{array}{l}\text { Black poly-ethylene } \\
\text { mulch } 0.150 \mathrm{~mm}\end{array}$ & $143.77 \mathrm{f}$ & $139.35 \mathrm{~g}$ & $25.79 \mathrm{e}$ & $20.83 \mathrm{i}$ & $15.11 \mathrm{de}$ & $13.95 \mathrm{~g}$ \\
\hline $\begin{array}{l}\text { Green poly-ethylene } \\
\text { mulch } 0.150 \mathrm{~mm}\end{array}$ & $134.16 \mathrm{~g}$ & $131.55 \mathrm{~h}$ & $23.71 \mathrm{f}$ & $19.62 \mathrm{j}$ & $14.38 \mathrm{e}$ & $13.35 \mathrm{gh}$ \\
\hline Rice straw at 10 ton & $152.16 \mathrm{e}$ & $148.11 \mathrm{ef}$ & $28.26 \mathrm{~cd}$ & $25.62 \mathrm{f}$ & $16.63 \mathrm{~d}$ & $15.70 \mathrm{f}$ \\
\hline Wheat straw at 10 ton. & $145.20 \mathrm{f}$ & $131.90 \mathrm{~h}$ & $27.83 \mathrm{~cd}$ & $22.36 \mathrm{~h}$ & $16.35 \mathrm{~d}$ & $15.05 \mathrm{f}$ \\
\hline \multicolumn{7}{|l|}{ Trade N. (rate/fed.) } \\
\hline Atazan $50 \mathrm{~g}$ & $116.50 \mathrm{~h}$ & $107.57 \mathrm{i}$ & $26.28 \mathrm{de}$ & $24.27 \mathrm{~g}$ & $16.50 \mathrm{~d}$ & $15.10 \mathrm{f}$ \\
\hline Ataz. $37.5 \mathrm{~g}+$ Min. ${ }^{*} 1 \%$ & $162.35 \mathrm{c}$ & $154.11 \mathrm{~cd}$ & $29.00 \mathrm{c}$ & $26.55 \mathrm{f}$ & $23.05 \mathrm{~b}$ & $21.65 \mathrm{bc}$ \\
\hline $\begin{array}{l}\text { Ataz. } 25 \mathrm{~g} \text { foll. } * * \text { by } \\
\text { Rice straw } 10 \text { ton }\end{array}$ & $184.05 \mathrm{a}$ & $179.70 \mathrm{ab}$ & $39.15 \mathrm{a}$ & $36.22 \mathrm{ab}$ & $26.19 \mathrm{a}$ & $25.22 \mathrm{a}$ \\
\hline $\begin{array}{l}\text { Ataz. } 25 \mathrm{~g} \text { foll. by Wheat } \\
\text { straw } 10 \text { ton }\end{array}$ & $183.62 \mathrm{a}$ & $178.76 \mathrm{ab}$ & $38.73 \mathrm{a}$ & $35.70 \mathrm{~b}$ & $26.15 \mathrm{a}$ & $25.10 \mathrm{a}$ \\
\hline Steler Star $300 \mathrm{~cm}^{3}$ & $149.54 \mathrm{e}$ & $143.21 \mathrm{fg}$ & $28.90 \mathrm{c}$ & $27.68 \mathrm{e}$ & $17.22 \mathrm{~d}$ & $17.40 \mathrm{e}$ \\
\hline Stel. $225 \mathrm{~cm}^{3}+$ Min. $1 \%$ & $162.00 \mathrm{c}$ & $158.91 \mathrm{c}$ & $30.92 \mathrm{~b}$ & $29.33 \mathrm{~d}$ & $23.00 \mathrm{~b}$ & $22.27 \mathrm{~b}$ \\
\hline $\begin{array}{l}\text { Stel. } 150 \mathrm{~cm}^{3} \text { foll. by } \\
\text { Rice straw10 ton }\end{array}$ & $183.98 \mathrm{a}$ & $182.25 \mathrm{a}$ & $39.32 \mathrm{a}$ & $36.95 \mathrm{a}$ & $26.14 \mathrm{a}$ & $25.61 \mathrm{a}$ \\
\hline $\begin{array}{l}\text { Stel. } 150 \mathrm{~cm}^{3} \text { foll. by } \\
\text { Wheat straw10 ton }\end{array}$ & $177.89 \mathrm{~b}$ & $176.49 \mathrm{~b}$ & $38.57 \mathrm{a}$ & $35.56 \mathrm{~b}$ & $25.27 \mathrm{a}$ & $24.81 \mathrm{a}$ \\
\hline Maister power $500 \mathrm{~cm}^{3}$ & $155.35 \mathrm{~d}$ & $150.42 \mathrm{de}$ & $32.58 \mathrm{~b}$ & $30.55 \mathrm{c}$ & $22.05 \mathrm{~b}$ & $21.15 \mathrm{~b}$ \\
\hline Hand howing (twice) & $142.89 \mathrm{f}$ & $139.75 \mathrm{~g}$ & $27.79 \mathrm{~cd}$ & $28.18 \mathrm{e}$ & $20.27 \mathrm{c}$ & $19.55 \mathrm{~d}$ \\
\hline untreated weed & $94.03 \mathrm{i}$ & $93.15 \mathrm{j}$ & $18.94 \mathrm{~g}$ & $17.76 \mathrm{k}$ & $13.29 \mathrm{e}$ & $12.89 \mathrm{~h}$ \\
\hline
\end{tabular}

*Min. $=$ Mineral oil. $* *$ foll.$=$ followed.

Any two means in the same column sharing same letters did not differ significantly by Duncan at $5 \%$ level of probability.

\subsubsection{Maize grains quality}

The data presented in (Table 5) showed that controlling maize weeds significantly increased the concentrations of carbohydrate and protein percentage in maize grains compared with the at reduced rate $\left(225 \mathrm{~cm}^{3} / \mathrm{fed}\right)$ tank mix with mineral oil whereas carbohydrate reached to $(88.4,85.2$ and $81.9 \%)$, but proteins were (10.1, 9.8 and $8.3 \%$ ) respectively, in the first season, and in the second season was same altitude. 
Table (5): Effect of mulching with herbicides in combinations on quality percentage in 2018 and 2019 seasons.

\begin{tabular}{|l|c|c|c|c|}
\hline \multirow{2}{*}{ Treatments } & \multicolumn{2}{|c|}{ Carbohydrate (\%) } & \multicolumn{2}{c|}{ Protein (\%) } \\
\cline { 2 - 5 } & $\mathbf{2 0 1 8}$ season & 2019 season & 2018 season & 2019 season \\
\hline $\begin{array}{l}\text { Black poly-ethylene mulch } \\
0.150 \mathrm{~mm}\end{array}$ & $71.3 \mathrm{~h}$ & $71.2 \mathrm{fgh}$ & $6.9 \mathrm{de}$ & $6.9 \mathrm{~cd}$ \\
\hline $\begin{array}{l}\text { Green poly-ethylene mulch } \\
0.150 \mathrm{~mm}\end{array}$ & $70.3 \mathrm{hi}$ & $68.4 \mathrm{gh}$ & $6.8 \mathrm{de}$ & $6.73 \mathrm{~cd}$ \\
\hline Rice straw at 10 ton & $75.8 \mathrm{fg}$ & $72.6 \mathrm{fgh}$ & $7.5 \mathrm{de}$ & $7.5 \mathrm{~cd}$ \\
\hline Wheat straw at 10 ton & $73.0 \mathrm{gh}$ & $72.3 \mathrm{fgh}$ & $7.3 \mathrm{de}$ & $7.2 \mathrm{~cd}$ \\
\hline \multicolumn{1}{|c|}{ Trade N. (rate/fed.) } & \multicolumn{5}{|c|}{} \\
\hline Atazan $50 \mathrm{~g}$ & $76.1 \mathrm{fg}$ & $75.9 \mathrm{def}$ & $7.8 \mathrm{cde}$ & $7.3 \mathrm{~cd}$ \\
\hline Ataz. $37.5 \mathrm{~g}+$ Min.* at $1 \%$ & $80.5 \mathrm{de}$ & $77.5 \mathrm{~b}-\mathrm{f}$ & $8.2 \mathrm{bcde}$ & $7.4 \mathrm{~cd}$ \\
\hline $\begin{array}{l}\text { Ataz. } 25 \mathrm{~g} \text { foll. } * * \text { by Rice straw } \\
10 \text { ton }\end{array}$ & $86.5 \mathrm{ab}$ & $84.0 \mathrm{ab}$ & $10.0 \mathrm{a}$ & $9.7 \mathrm{ab}$ \\
\hline $\begin{array}{l}\text { Ataz. } 25 \mathrm{~g} \text { foll. by Wheat straw } \\
10 \text { ton }\end{array}$ & $84.8 \mathrm{bc}$ & $83.1 \mathrm{abc}$ & $9.5 \mathrm{abc}$ & $8.0 \mathrm{~cd}$ \\
\hline Steler Star $300 \mathrm{~cm}^{3}$ & $77.5 \mathrm{ef}$ & $76.7 \mathrm{cdef}$ & $7.9 \mathrm{cde}$ & $6.83 \mathrm{~cd}$ \\
\hline Stel. $225 \mathrm{~cm}^{3}+$ Min. at $1 \%$ & $81.9 \mathrm{~cd}$ & $81.1 \mathrm{a}-\mathrm{e}$ & $8.3 \mathrm{bcd}$ & $7.6 \mathrm{~cd}$ \\
\hline $\begin{array}{l}\text { Stel. } 150 \mathrm{~cm}^{3} \text { foll. by Rice } \\
\text { straw10 ton }\end{array}$ & $88.4 \mathrm{a}$ & $87.3 \mathrm{a}$ & $10.1 \mathrm{a}$ & $10.0 \mathrm{a}$ \\
\hline $\begin{array}{l}\text { Stel. } 150 \mathrm{~cm}^{3} \text { foll. by Wheat } \\
\text { straw10 ton }\end{array}$ & $85.2 \mathrm{bc}$ & $84.4 \mathrm{ab}$ & $9.8 \mathrm{ab}$ & $9.7 \mathrm{ab}$ \\
\hline Master power $500 \mathrm{~cm}^{3}$ & $83.8 \mathrm{bc}$ & $82.6 \mathrm{abcd}$ & $9.5 \mathrm{abc}$ & $8.3 \mathrm{bc}$ \\
\hline $\begin{array}{l}\text { Hand howing twice at } 20 \text { and } \\
40 \text { DAS }\end{array}$ & $80.1 \mathrm{de}$ & $75.3 \mathrm{efg}$ & $7.5 \mathrm{de}$ & $7.5 \mathrm{~cd}$ \\
\hline untreated weed & $67.3 \mathrm{i}$ & $66.2 \mathrm{~h}$ & $6.5 \mathrm{e}$ & $6.6 \mathrm{~d}$ \\
\hline
\end{tabular}

*Min. $=$ Mineral oil. $* *$ foll. $=$ followed.

Any two means in the same column sharing same letters did not differ significantly by Duncan at $5 \%$ level of probability.

While, the lowest values of carbohydrate and protein percentages in maize grains were recorded at full rates alone of Atazan and Steler star whereas, carbohydrate were $(76.1$ and $77.5 \%)$ and protein were $(7.8$ and $7.9 \%)$ respectively, in the first season, the second season was similar trend. These results may be due to the less competition for nutrients, water and light through limiting weeds infestation by effective weed control using combination of different herbicides with straw mulching or adding mineral oil. Hussein (1996) reported that, controlling weeds in maize field could save 75 , 11 and $54 \mathrm{~kg} / \mathrm{ha}$ of N, P and $\mathrm{K}$ and 90, 1029 and $99 \mathrm{~g} / \mathrm{ha}$ of $\mathrm{Zn}, \mathrm{Fe}$ and $\mathrm{Mn}$, respectively. Similar results were obtained by Sinha et al. (2005), Ahmed et al. (2008) and El-Metwally et al. (2009).

\section{REFERENCES}

Abouzinea H. F., Ahmed M. A., Eldabaa M. A. T. and Abd El Wahed M. S. A. (2013). A comparative study on the productivity of two yellow maize cultivars grown under various weed control managements. Middle East J. Agric. Res., 2(2): 56-67.

Afzal I., Noor M. A., Bakhtavar M. A., Ahmad A. and Haq Z. (2015). Improvement of spring maize (Zea mays) performance through physical and physiological seed enhancements. Seed Sci. \& Technol., 43:112

Agricultural Statistics (2019). Ministry of Agricultural and land reclamation. Economic Affairs Sector. Summer Crops.

Ahmed S. E., Shams H. M., El-Metwally I. M., Shehata M. N. and El-Wakeel M. A. (2008). Efficiency of some weed control treatments on growth, yield and its 
attributes of maize (Zea mays L.) plants and associated weeds. J. Agric. Sci. Mansoura Univ., 33(7): 4777-4789.

Amin M. H. A., Rahaman M. S. and Azad M. O. K. (2008). Effect of initial moisture content and different storage container on the quality of grass pea (Lathyrus sativa) seed. Int'1. J. Sust. Crop Prod., 3 (3): 18-24.

Anonymous (2006). In: Crop Protection Handbook. Meister Publishing Company, Ohio,USA.

A.O.A.C. (2000). Methods of analysis, Association of Official Agriculture Chemistry, $17^{\text {th }}$ Ed. Washington, DC, USA.

Bond W. and Grundy A.C. (2001). Nonchemical weed management in organic farming system. Weed Res.,41:383-405.

Devendra R., Umamahesh V., Prashad T. V. R., Prashad T. G. and Asha S. T. A. (2004). Influence of surfactants on efficacy of different herbicides in control of Cyperus rotundus and Oxalis latifolia. Curr. Sci., 86: 8-86.

Duncan B. O. (1955). Multiple Range Test F. tests. Biometercs, 11: 1-42.

El-Metwally I. M., Saudy H. S. S. and El-Ashry S. M. (2009). Response of associated weeds to irrigation intervals, weed management and nitrogen forms. J. Agric. Sci. Mansoura Univ., 34(5): 5003-5017.

Elmer W. H. (2000). Comparison of plastic mulch and nitrogen form on the incidence of verticillium wilt of eggplant. Plant Disease, 84(11):1231-1234

Fazal M., Kawsar A., Iftikhar K., Hujjat U. K. and Muhammad A. (2009). Efficacy of various herbicides against weeds and their impact on yield of maize. Pak. J. weed Sci. Res. 15 (2-3): 191-198.

Gomez K.A. and Gomez A.A. (1984). Statistical Procedures for Agricultural Research $\left(2^{\text {nd }}\right.$ Ed.). John Wiley and Sons. New York. USA. $680 p$.

Hussein, H. F. (1996). Interactive effects of nitrogen sources and weed control treatments on growth and nutrients uptake of weeds and grain yield of maize (Zea mays L.) plants. J. Agric. Sci. Mansoura Univ., 21(10): 3437-3449.

Khaliq T., mohmood T. and Masood A. (2004). Effectiveness of farmyard manure, poultry manure and nitrogen for corn (Zea mays) productivity. Int'l. J. Agric. Biol., 2: 260263.
Knezevic D., Rosandic A., Kondic D., Radosavac A. and Rajkovic D. (2017a). Effect of gluten formation on wheat quality. Columella J. Agri. and Env. Sci., 4(1):169174.

Knezevic D., Zecevic V., Micanovic D., Menkovska M. and Glumac S. (2017b). Effect of environment to wheat quality properties. XII Int. Conf. "Knowledge capital of the future" knowledge without borders", V. Banja, Serbia. Int'l J. Inst. of Knowledge Management, 16(4):609-614.

Mahmoodi S. and Ali R. (2009). Estimation of critical period for weed control in corn in Iran. Proceedings of World Academy of Sci., engine. And tech., 37: 67-72.

Monks C.D., Monks D.W., Basden T., Selders A., Poland S. and Rayburn E. (1997). Soil temperature, soil moisture, weed control, and tomato (Lycopersicon esculentum) response to mulching. Weed Tech., 11(3):561-566.

Noor M., Muhammad A., Abdul G., Abdus S. and Muhammd A. (2012). Comparative efficiency of new herbicides for weed control in maize (Zea mays L.). Pak. J. Weed Sci. Res., 18(2): 247-254.

Rahman M.A., Khan M.A.H. and Rahman M.M. (2002). Mulch induced morphophysiological adaptation of quality protein maize. Bangladesh J. Agric. Res., 27 (3), 329-340.

Rao S.(2000). Principles of weed science. $2^{\text {nd }}$. Science Publishers. 526p. New York,USA

Revathy L.N. (2003). Plastic mulching works for cotton. The Hindu Business Line.

Saudy H.S. (2013). Easily practicable packages for weed management in maize. Afr. Crop Sci. J., 21(4):291-301.

Silva T.M., Medeiros A.N., Oliveira R.L., Gonzaga N.S., Ribeiro M. D., Bagaldo A.R. and Ribeiro O.L. (2015). Peanut cake as a substitute for soybean meal in the diet of goats. J. Anim. Sci., 93 (6): 2998-3005.

Sinha S.P., Prasad S.M. and Singh S.J. (2005). Nutrient utilization by winter maize (Zea mays L.) and weeds as influenced by integrated weed management. Indian J. Agron., 50(4): 303-304.

Sopeña F., Maqueda C. and Morillo E. (2009). Controlled release formulations of herbicides based on micro-encapsulation. Cien. Inv. Agr., 35(1):27-42. 
Täckholm V. (1974). Student flora of Egypt, $2^{\text {nd }}$ Ed., Cairo University, Cairo, Egypt 888 p.

Teasdal J. R. and Mohler C. L. (2000). The quantitative relationship between weed emergence and physical properties of mulches. Weed Sci., 48(3): 385-392.

The Pesticide manual, PM- Tomlin C. D. S. (2012). (15 ${ }^{\text {th }}$ Ed). British Crop Production council.
Varga P., Bcrcs I., Rcisinger P. and Busak P. (2011). The influence of soil herbicides on weeds in maize. Proc. German Conf. Weed Biology and Weed Control, Germany, 17: 641-646.

Weed Science Society of America (WSSA) (2011). Resistance, WSSA Classification of Herbicide Resistance Mechanism of Action, pp. 1-6! http://www.wssa.net.

\section{تأثير بعض مبيدات الحشائش وانواع تغطية والتكامل بيذهما على انتاجية محصول الأرة الثامية ومكافحة الحشائش المصاحبة بئنة \\ رشا جمال محمد ابو الحسن}

المعمل المركزى لبحوث الحشائش - مركز البحوث الزراعية ـ الجيزة ـ مصر.

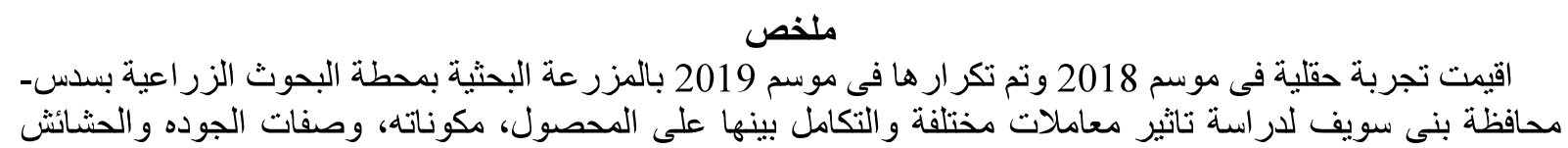

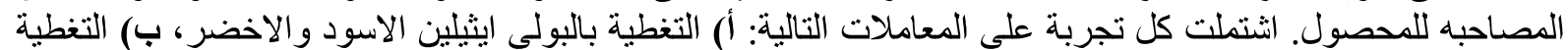

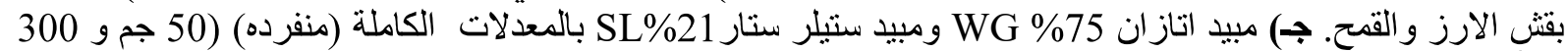

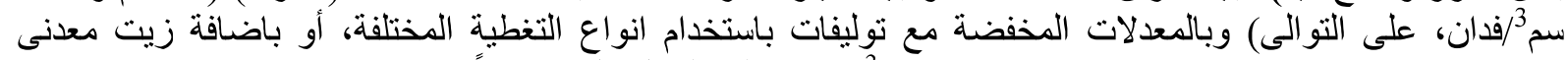

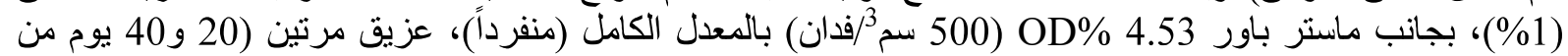

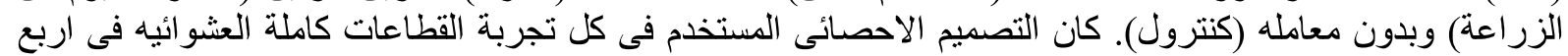

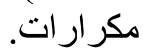

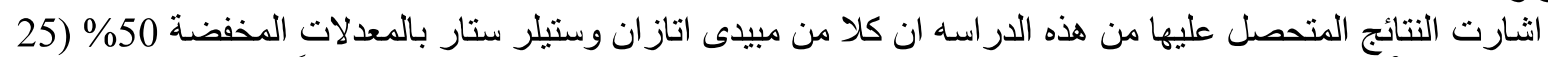

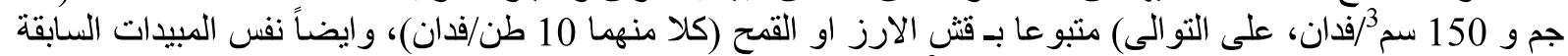

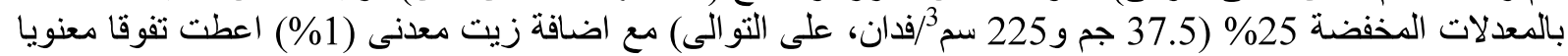

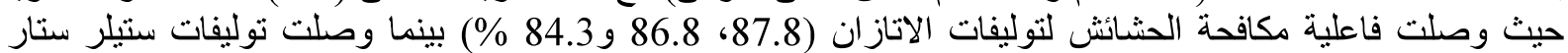

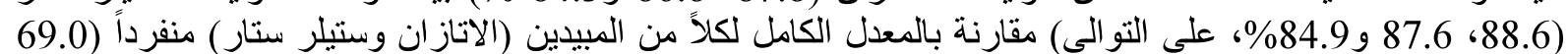

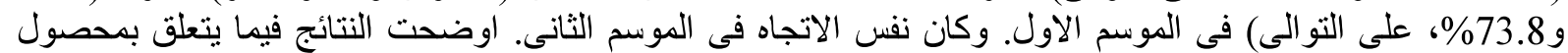

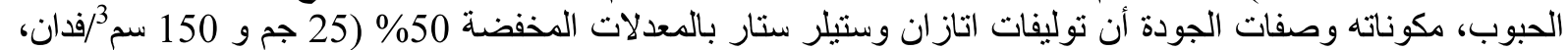

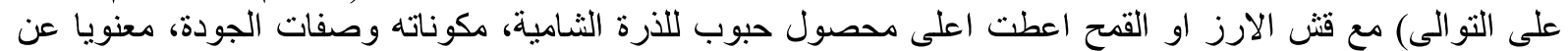

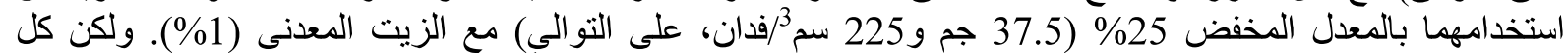

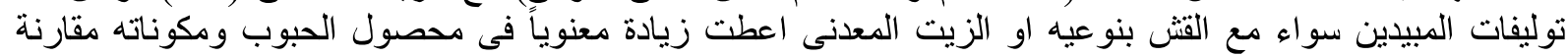

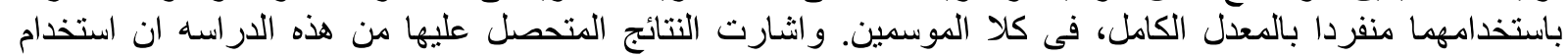

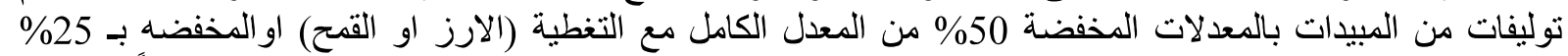

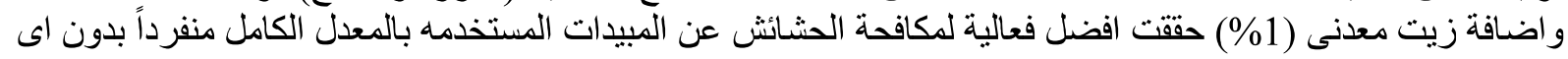

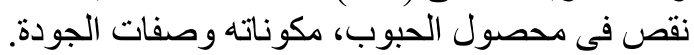

